\title{
Przejawy korozji biologicznej kamienia budowlanego i problemy związane z jego rewaloryzacją
}

\author{
Marek Rembiś ${ }^{1}$
}

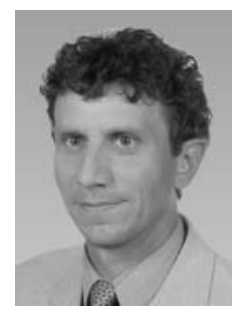

Symptoms of biological corrosion of a building stone and the problems of its restoration. Prz. Geol., 67: 710-716; doi: 10.7306/2019.41

A b s tract. Biological corrosion (biodeterioration) of a building material resulting from the presence of microand macroorganisms that occupy the stone impairs its properties and may even lead to its full damage (disintegration). The stone conservation procedures usually start with surface disinfection and are followed by consolidation (stone structure strengthening) and surface hydrophobization (inducing water repellency). Thus, the stone is penetrated almost simultaneously by a range of various chemicals. The combined interaction of the substances of various chemistry may lower their effectiveness and even result in a failure to obtain the desired stone restoration. Author's SEM observations have proved that some of the biocidal substances hamper a later introduction of chemicals, which either form appropriate films consolidating the sandstone structure or make the stone hydrophobic. Such adverse effects of the multichemical stone treatment have also been evidenced by the measurements of the sandstone compression strength and water absorbability.

Keywords: building sandstones, biodeterioration, consolidation, hydrophobization

Skały stosowane jako kamień budowlany są materiałem o zróżnicowanej odporności na działanie niszczących czynników klimatycznych i antropogenicznych. Sposób i przejawy destrukcji różnych typów skał znajdujących się w różnorodnych warunkach środowiskowych były wielokrotnie opisywane przez specjalistów reprezentujących różne dziedziny nauki. Obszerna literatura na ten temat znajduje się np. w pracach Amoroso i Fassina (1983), Prikryla i Smitha (2007) oraz Siegesmunda i Snethlage'a (2011). Czynniki, które przyczyniają się do niszczenia kamienia w budowlach, powszechnie dzieli się na chemiczne, fizyczne, mechaniczne i biologiczne. Niejednokrotnie działają one na kamień łącznie, przyspieszając jego deteriorację. Skutkiem różnorodnych procesów niszczących zachodzących na powierzchni i wewnątrz kamienia są zarówno jego przekształcenia wizualne, np. zmiany barwne, jak i powstawanie nawarstwień, ubytków i spękań, prowadzących do zmniejszania zwięzłości kamienia, a nawet do rozpadu elementów kamiennych.

\section{KOROZJA BIOLOGICZNA KAMIENIA BUDOWLANEGO}

Przez korozję biologiczną (biodeteriorację) obiektu kamiennego rozumie się utratę jego właściwości użytkowych spowodowaną czynnikami biologicznymi w efekcie zasiedlenia obiektu przez mikro- i makroorganizmy (Allsopp i in., 2004). W początkowym stadium na powierzchni kamienia tworzą się błony biologiczne składające się z komórek drobnoustrojów oraz wydzielanych przez nie śluzów, czyli zewnątrzkomórkowych polimerów. Przyczepiają się one do podłoża, łatwo pochłaniając i zatrzymując wilgoć. Obecność takich biofilmów na kamieniu wywołuje zmiany właściwości fizykochemicznych podłoża i inicjuje proces biokorozji.

Biocenoza występująca na kamieniu jest reprezentowana przez różne grupy organizmów. Należą do nich: drobnoustroje heterotroficzne (bakterie i grzyby) i autotroficzne (bakterie siarkowe, nitryfikacyjne, glony), a także mszaki, porosty i roślinność wyższa.

Drobnoustroje heterotroficzne są powszechne w środowisku naturalnym, charakteryzując się łatwością rozprzestrzeniania i niewielkimi wymaganiami pokarmowymi (Warscheid, Braams, 2000). Występują zarówno na powierzchni kamienia (epility), nadtrawiając jego powierzchnię, jak i w jego wnętrzu (endolity), w porach na głębokości 2-4 mm pod powierzchnią kamienia oraz w szczelinach (chasmolity), zasiedlanych następnie przez inne drobnoustroje. Charakteryzują się dynamicznym rozwojem, odżywiają się resztkami roślinnymi (celulozą, skrobią, białkami) oraz resztkami zwierzęcymi (białkami, tłuszczami, chityną). Do zainicjowania ich wzrostu na kamieniu wystarczające są mikrozanieczyszczenia organiczne w postaci np. kurzu. Tworzą różnorodne formy morfologiczne, często złożone, takie jak: łańcuszki, pakiety, grona i in. (ryc. 1). Szybko ulegają samoistnemu rozpadowi pod wpływem własnych enzymów. Wytwarzają duże ilości biogennych kwasów tworzących sole i chelatujących jony metali, głównie $\mathrm{Ca}^{+2}, \mathrm{Mn}^{+2}, \mathrm{Fe}^{+3}, \mathrm{Al}^{+3}$ oraz $\mathrm{Si}^{+4}$. Wydzielają do podłoża kamiennego znaczne ilości kwasów organicznych: mlekowego, cytrynowego, fumarowego, szczawiowego i 2-ketoglukonowego, które rozpuszczają składniki zarówno wapieni, piaskowców wapnistych, jak i granitów. Dodatkowo, zwiększona objętość rozpuszczalnych soli i chelatów wywołuje powstawanie naprężeń w strukturze skały, a po przekroczeniu ich granicznej wartości - jego pękanie.

Drobnoustroje autotroficzne odgrywają istotną rolę w niszczeniu materii skalnej. Reprezentowane są przez organizmy chemosyntetyzujące (chemotrofy) oraz fotosyntetyzujące (fototrofy) (Flores i in., 1997). Chemotrofy budują swoje ciała ze związków organicznych wytworzonych przez siebie na drodze redukcji atmosferycznego tlenku węgla (IV). Należą do nich bakterie siarkowe i bakterie

\footnotetext{
${ }^{1}$ AGH Akademia Górniczo-Hutnicza, Wydział Geologii, Geofizyki i Ochrony Środowiska, al. A. Mickiewicza 30, 30-059 Kraków; mrembis@geol.agh.edu.pl
} 


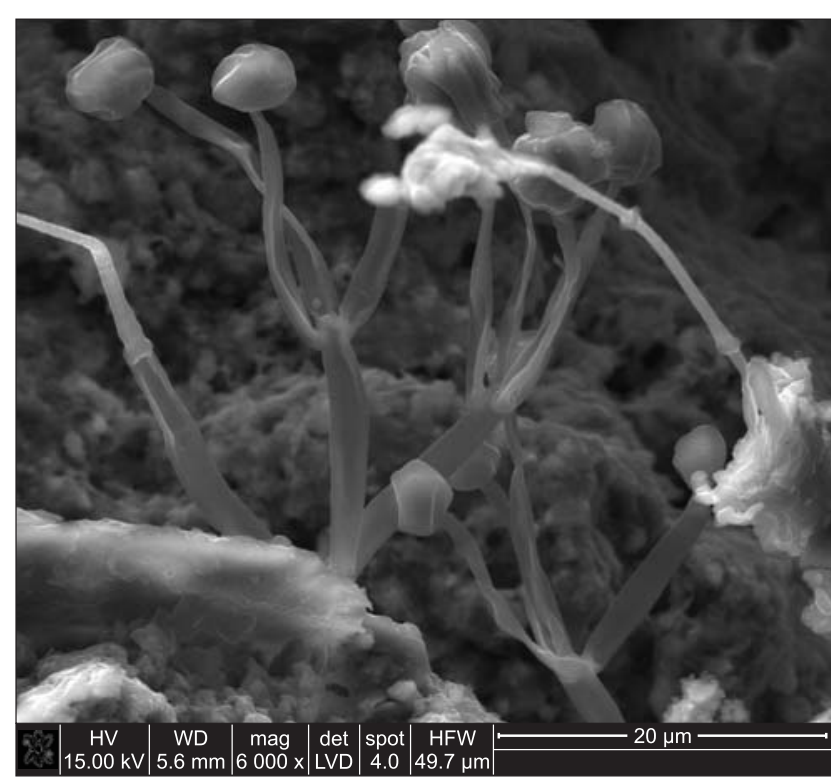

Ryc. 1. Grzyby zasiedlające wnętrze piaskowca. Obraz SEM Fig. 1. Fungi occupying the inner part of a sandstone. SEM image

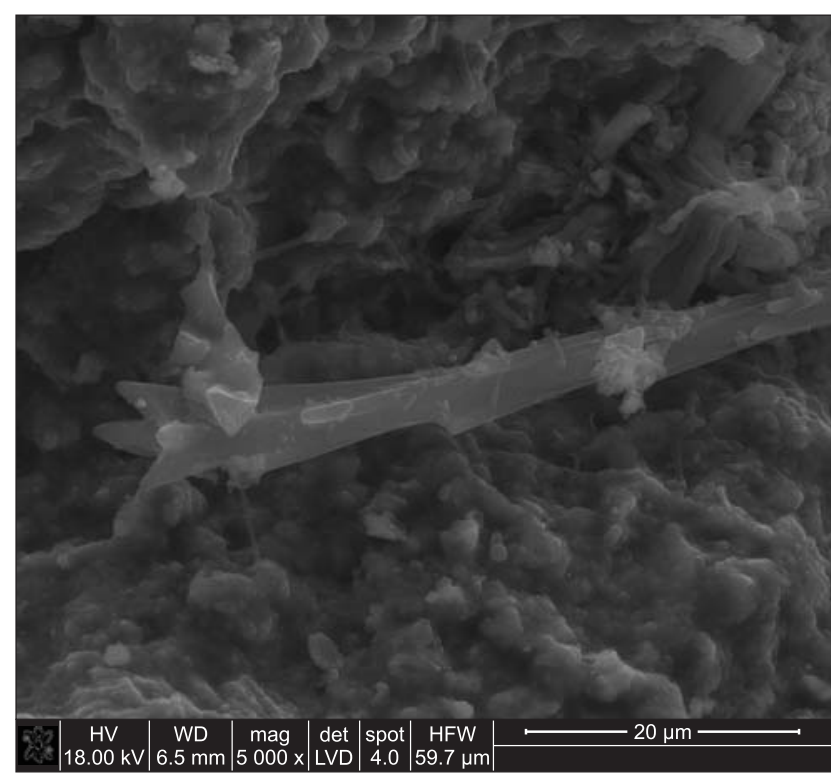

Ryc. 2. Ryzoidy mszaków rozwijające się we wnętrzu piaskowca. Obraz SEM

Fig. 2. Rhisoids of bryophytes developed inside a sandstone. SEM image

nitryfikacyjne. Bakterie siarkowe (np. łac. Thiobacillus thiooxidans) utleniają wnikające w kamień związki siarki, co prowadzi do powstania kwasu siarkowego, wywołującego w skałach węglanowych rozpuszczanie węglanu wapnia i tworzenie się nawarstwień gipsowych. Bakterie nitryfikacyjne (np. łac. Nitrosomonas) wywołują utlenianie amoniaku i azotanów (III) do kwasów azotowego (III) i azotowego (V). W wyniku reakcji tych kwasów z węglanem wapnia lub innymi minerałami powstają łatwo rozpuszczalne związki wymywane ze struktury skały. Makroskopowym efektem działania tych drobnoustrojów jest osypywanie się kamienia i tzw. wysolenia, związane z krystalizacją chlorków, siarczanów i azotanów. Fototrofy zawierają chlorofil lub inne barwniki i wykorzystują światło jako źródło energii potrzebnej do budowy tkanek. Należą do nich np. cyjanobakterie (sinice), umownie zaliczane do glonów. Są one organizmami pionierskimi, zasie-

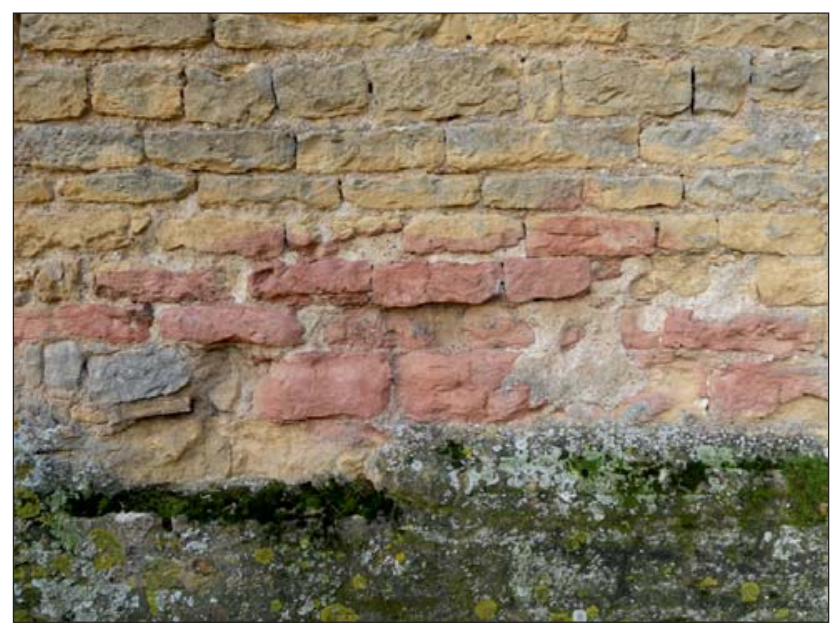

Ryc. 3. Zewnętrzna elewacja romańskiej Bazyliki Najświętszego Serca Pana Jezusa (Basilique du Sacré-Cœur) w Paray-le-Monial (Francja). Wapień w dolnej części ściany ulegający rozpadowi w wyniku działalności pokrywających go mszaków i porostów

Fig. 3. The outer elevation of the Romanesque basilica of the Sacred Heart of Jesus (Basilique du Sacré-Cœur) of Paray-le-Monial (France). Being covered by colonies of bryophytes and lichens, the limestones of the lower part of the façade disintegrate

dlającymi miejsca potencjalnie niedostępne dla organizmów żywych, które przekształcają w taki sposób, że stają się one dogodne do zasiedlenia przez inne grupy organizmów. Zdolne są do unoszenia się na wietrze (aerofity) i do przetrwania niekorzystnych warunków środowiska, takich jak brak wody lub wysoka temperatura. W wyniku działania ich procesów metabolicznych zachodzi uwalnianie substancji chemicznych umożliwiających im penetrację i wrastanie w podłoże kamienne. Jako produkty uboczne metabolizmu powstają nieorganiczne kwasy: mlekowy, szczawiowy, bursztynowy, octowy i pirogronowy. Szczególnie ekspansywna w stosunku do powierzchni wapiennych jest cyjanobakteria (łac. Scytonema drilosiphon), która powoduje intensywne rozpuszczanie ich składników (Ortega-Calvoa i in., 1991).

Mszaki są dość silnie chemicznie związane z kamieniem, wydzielając związki rozkładające podłoże (cukry, aminokwasy, kwasy organiczne). Za pomocą ryzoidów doprowadzają do mechanicznych uszkodzeń kamienia i niszczenia poszczególnych jego elementów (ryc. 2, 3). Ich obecność sprzyja utrzymywaniu zwiększonej wilgotności podłoża umożliwiającej rozwój innych organizmów.

Porosty lub grzyby zlichenizowane (łac. Lichenes) sa formami składającymi się z dwóch symbiotycznie żyjących organizmów: grzyba (mikobionta) i glona (fikobionta). Przylegają do powierzchni kamienia całym organizmem (porosty skorupiaste) lub tylko chwytnikami (porosty listkowate i krzaczkowate). Są zdolne do absorbowania dużych ilości wody, wskutek czego wielokrotnie zwiększają swoją masę i objętość, powodując rozsadzanie wierzchnich warstw podłoża kamiennego (ryc. 3, 4). Wytwarzają ponad 230 agresywnych związków organicznych i kwasów tzw. porostowych, będących pochodnymi kwasów tłuszczowych i fenoli. Niektóre z nich, takie jak kwasy norstyktynowy, styktynowy i usninowy, tworzą związki kompleksowe metali, między innymi z krzemianami, pochodzącymi z podłoża (Garg i in., 1988). Z kolei kwas szczawiowy dość łatwo wiąże wapń zawarty w podłożu i przyspiesza rozpuszczanie $\mathrm{SiO}_{2}$. 


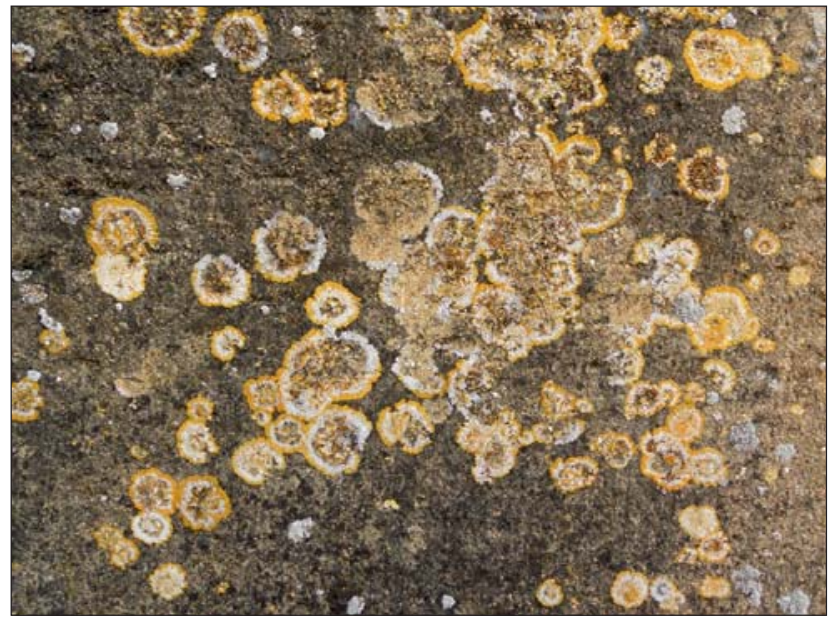

Ryc. 4. Zewnętrzna elewacja romańskiej Bazyliki Najświętszego Serca Pana Jezusa (Basilique du Sacré-Cœur) w Paray-le-Monial (Francja). Zmiany barwne i liczne ubytki na powierzchni wapienia powstałe w wyniku działania porostów

Fig. 4. The outer elevation of the Romanesque basilica of the Sacred Heart of Jesus (Basilique du Sacré-Cœur) of Paray-le-Monial (France). The changes of colours and many cavities on the limestone surfaces have been caused by lichens

Rośliny wyższe działają na kamień mechanicznie poprzez rozwój systemu korzeniowego w jego szczelinach kapilarnych, co prowadzi do jego rozkruszania. Ponieważ w wydzielinach korzeniowych są obecne cukry, aminokwasy, kwasy organiczne, nukleotydy i enzymy, dochodzi również do tworzenia się organometalicznych kompleksów w obecności wody i rozpuszczania warstwy powierzchniowej kamienia.

\section{KONSERWACJA KAMIENIA PODDANEGO BIODETERIORACJI}

Zabiegi konserwatorskie, jakim poddawany jest kamień, mają na celu usunięcie przejawów i skutków działania procesów deterioracji, a w niektórych przypadkach także odtworzenie jego pierwotnych cech. Dodatkowo ich zadanmiem jest również zabezpieczenie kamienia przed czynnikami niszczącymi działającymi w przyszłości. Podstawowe zabiegi konserwatorskie można podzielić na kilka głównych grup, do których należą: odsalanie i czyszczenie kamienia (fizyczne i chemiczne usuwanie substancji i związków chemicznych powstałych na jego powierzchni lub wnętrzu), dezynfekcja (usuwanie organizmów zasiedlających kamień), a także wzmocnienie zdezintegrowanych fragmentów kamienia, klejenie pęknięć, uzupełnianie ubytków i zabezpieczenie powierzchni (hydrofobizacja) (Amoroso, Fassina, 1983; Ferreira Pinto, Delgado Rodrigues, 2008; Siegesmund, Snethlage, 2011).

Kamień, który uległ deterioracji w wyniku działania czynników biologicznych, powinien zostać poddany zabiegom konserwatorskim obejmującym przede wszystkim dezynfekcję. Ponieważ biokorozja wyraża się między innymi osłabieniem zwięzłości kamienia, wymagane jest także działanie polegające na wzmocnieniu jego struktury oraz hydrofobizacji zabezpieczającej jego powierzchnię.

Przeznaczeniem preparatów biobójczych jest niszczenie i zapobieganie działaniu organizmów żywych (Schna- bel, 1991). Dokonuje się to dzięki obecności w nich substancji czynnych, takich jak: fenol, chlorowce i ich pochodne, alkohole, aldehydy, związki utleniające, kwasy organiczne i nieorganiczne oraz związki azotu, np. aminy alifatyczne i czwartorzędowe sole alkiloamoniowe. Dość skuteczne w konserwacji kamienia są ostatnie z wymienionych. Ich adsorpcja na powierzchni kamienia powoduje usunięcie z niej cząstek wody i wytworzenie monomolekularnej warstwy ochronnej (nietrwałych, odwracalnych kompleksów z substancjami obecnymi na powierzchni. Działanie biobójcze polega na oddziaływaniu kulombowskim soli alkiloamoniowych z ujemnie naładowaną powierzchnią ściany komórkowej mikroorganizmów.

Zabieg strukturalnego wzmocnienia kamienia powoduje wprowadzenie w jego przestrzeń porową nowej substancji, która w różnym stopniu modyfikuje mikrostrukturę tego materiału. Od rodzaju i ilości wprowadzonej do skały substancji czynnej zawartej w preparacie oraz dobrej, wzajemnej spójności obu materiałów zależy skuteczność impregnacji wzmacniającej. Warunkowana jest ona bowiem sposobem wiązania składników mineralnych przez substancję wzmacniającą i charakterem zmodyfikowanej struktury porów. Preparaty do wzmacniania strukturalnego powinny posiadać określone cechy użytkowe zapewniające skuteczność wykonania tego zabiegu konserwatorskiego. Winny wnikać na znaczną głębokość w głąb kamienia, tworząc spoiwo odporne na zmienne warunki atmosferyczne, zachowując istotne właściwości fizyczne kamienia, a szczególnie mrozoodporność, przepuszczalność pary wodnej i współczynnik rozszerzalności cieplnej. Ich zastosowanie nie powinno powodować powstawania zmian barwnych na powierzchni kamienia, ani też naprężeń i mikropęknięć w jego wnętrzu. Efekt wzrostu zwięzłości kamienia, wyrażony poprawą jego cech mechanicznych, powinien być wyraźny i trwały. Stosowane obecnie preparaty to głównie związki organiczne, takie jak: tetraalkoksysilany, alkilotrialkoksysilany, polisiloksany, żywice epoksydowe, poliuretany, poliestry oraz różnego rodzaju hybrydy silikonowe, preparaty akrylowe i winylowe (Weber, 1975; Arnold, 1978; Grissom, Weiss, 1981; Abe, Gunji, 2004; Wheeler, 2005; Favaro i in., 2006). W mniejszym stopniu są stosowane związki nieorganiczne, np. fluorosilikaty lub wodorotlenek baru. Wysoką skuteczność i jakość prac konserwatorskich zapewnia stosowanie związków krzemoorganicznych, w których substancją czynną są alkoksysilany, a zwłaszcza tetraetoksysilan. Preparaty takie głęboko penetrują przestrzeń porową kamienia, po czym przy udziale wilgoci zawartej w powietrzu, zachodzi ich hydrolityczna polikondensacja, w wyniku której początkowo powstaje nietrwały kwas ortokrzemowy, ulegający przekształceniu w kwas metakrzemowy, a następnie w żel krzemionkowy.

Hydrofobizacja ma za zadanie utworzenie warstwy zabezpieczającej kamień przed niszczącym działaniem wody poprzez zamykanie kapilar kamienia lub ograniczenie ich zwilżalności. Jest ona szczególnie skuteczna i bezpieczna dla kamienia, gdy obejmie jak największą jego część (tzw. hydrofobizacja strukturalna), a jednocześnie umożliwia dyfuzję pary wodnej, zapewniając także spełnienie przez środek hydrofobowy szeregu warunków związanych z kompatybilnością względem impregnowanego podłoża. Zabieg hydrofobizacji jest realizowany przy użyciu np. roztworów żywicy metylosilikonowej, polikrzemianów, mikroemulsji silikonowch, wosków i parafin. 


\section{CEL BADAŃ}

Wykonanie zabiegów dezynfekcji, konsolidacji i hydrofobizacji kamienia wymaga niemal równoczesnego wprowadzenia $\mathrm{w}$ jego przestrzeń porową różnych preparatów chemicznych. Zasadniczo preparaty biobójcze mają niską reaktywność chemiczną i w związku z tym nie powodują deterioracji kamienia. Ponadto powszechnie uważa się, że nie mają one wpływu na skuteczność działania innych środków stosowanych do konserwacji kamieni (Fernandes, 2006; Pinna i in., 2012). Ponieważ jednak pokrywają one jego powierzchnię oraz wnikają w jego przypowierzchniowe pory, mogą się przyczynić do zmiany natury chemicznej powierzchni ziaren lub struktury przestrzeni porowej konserwowanego kamienia bądź też innych jego cech fizycznych. Jeśli pod wpływem dezynfekcji dochodziłoby do zmiany fizycznych lub chemicznych właściwości podłoża, prowadzona w dalszej kolejności aplikacja preparatów hydrofobizujących i wzmacniających strukturalnie mogłaby zachodzić tylko powierzchniowo, wpływając na jej nikłą skuteczność. Informacja o zmianach mikrostrukturalnych, jakie dokonują się w kamieniu, w którym zaaplikowano materiały biobójcze oraz preparaty strukturalnie wzmacniające i hydrofobizujące, ma zatem istotne znaczenie dla przeprowadzenia skutecznych prac konserwatorskich obiektów.

Celem niniejszej pracy było określenie wpływu obecności różnego rodzaju preparatów biobójczych na skuteczność strukturalnego wzmocnienia i hydrofobizacji kamienia. Cel ten został zrealizowany poprzez wykonanie badań mikrostrukturalnych i oceny wybranych właściwości fizyczno-mechanicznych skał, uprzednio zdezynfekowanych i zabezpieczonych biokorozyjnie, a następnie wzmocnionych strukturalnie lub zhydrofobizowanych.

\section{MATERIAŁ BADAWCZY I METODYKA BADAŃ}

W badaniach wykorzystano cztery preparaty biobójcze: - Rocima 101 - produkowany przez Hamburską Spółkę Handlowa, H.S.H. Sp. z o.o., zawiera w swoim składzie: 40-60\% chlorek N,N-didecylo-N,N-dimetyloamoniowy oraz 20-25\% alkohol izopropylowy;

- Impuls 70-AN (Przedsiębiorstwo Innowacyjno-Wdrożeniowe „Impuls”) - składa się z 14,5\% chlorku N,N-didecylo-N,N-dimetyloamoniowym, $<5 \%$ kationowych środków powierzchniowo czynnych, 5-15\% niejonowych środków powierzchniowo czynnych i $<5 \%$ soli EDTA;

- ABM-1 - firmy MDA Sp. z o.o., jest złożony z N-3-aminopropylo-N-alkilo(C10-C14)-1,3-propanodiaminy, propionianu N,N-dialkilo(C10-C16)-N-metylo-N-poli(oksyetyleno)amoniowego, chlorku N,N-dialkilo(C10-C14)-N,Ndimetyloamoniowego oraz octanu 2-[3-(dodekanoiloamino)]propylodimetyloamoniowego;

- Boramon - produkcji Przedsiębiorstwa ALTAX Sp. z o. o., składa się z 24\% chlorków benzyloalkilo (C12-16) dimetyloamoniowych oraz 5\% kwasu borowego.

Spośród szerokiej gamy preparatów zawierających tetraetoksysilan, do badań wybrano dwa preparaty:

- KSE 500E firmy Remmers jest oparty jest na estrach etylowych kwasu ortokrzemowego o zawartości substancji czynnej wynoszącej ok. 85\% wag. i ilości wytrąconego żelu wynoszącej ok. $500 \mathrm{~g} / \mathrm{l}$;

- Sarsil OH-500 firmy Zakład Chemiczny „Silikony Polskie” Sp. z o.o. jest hydrofilowym preparatem zawierają- cym jako substancję czynną estry etylowe kwasu ortokrzemowego o standardowym stopniu polikondensacji.

Jako preparaty o działaniu hydrofobizującym wybrano:

- Funcosil BI firmy Remmers, który jest alkiloalkoksysilanem z dodatkami. Substancję czynną stanowią silany obecne w zawartości ok. 20\% wag., a zawartość polisiloksanów po wytworzeniu substancji czynnej wynosi $12 \%$ wag.;

- Asolin WS firmy Schomburg - jest preparatem rozpuszczalnikowym, na bazie siloksanów oligomerycznych $\mathrm{z}$ długimi grupami alkilowymi.

Do badań wybrano powszechnie stosowane w budownictwie piaskowce dolnojurajskie z mezozoicznego obrzeżenia Gór Świętokrzyskich, które reprezentują formację drzewicką (Deczkowski, Franczyk, 1988; Dadlez i in., 2008) i pochodzą ze złoża Śmiłów 4. Są to drobnoziarniste piaskowce o ubogim spoiwie krzemionkowym z domieszka ilastego i żelazistego, zawierające przewarstwienia iłowców oraz wkładki uwęglonej flory i sferosyderytów (Marek, Pajchlowa, 1997). Piaskowce formacji drzewickiej charakteryzują się znaczną nasiąkliwością (7-11\%) i niewielką wytrzymałością na ściskanie wynoszącą od 17 do $51 \mathrm{MPa}$ (Rembiś, 2013). Powoduje to, że są one szczególnie podatne na niszczenie, w tym także biodeteriorację i w trakcie prac konserwatorskich jest powszechnie wykonywana ich konsolidacja i hydrofobizacja.

Badania wykonano na 20 próbkach piaskowców ze złoża Śmiłów 4 (kostek sześciennych o boku $50 \mathrm{~mm}$ ), podzielonych na 5 serii po 4 próbki. Powierzchnie kostek pokryto (metodą oprysku) preparatami biobójczymi, stosując dla każdej serii inny preparat. Następnie każdą z próbek wchodzących w skład serii nasycono jednym z preparatów do strukturalnego wzmocnienia lub do hydrofobizacji. Jako poziom odniesienia zmian mikrostrukturalnych przyjęto serię próbek, które nie były poddane dezynfekcji środkami biobójczymi, a jedynie zaimpregnowane preparatami wzmacniającymi lub hydrofobizującymi.

Nasycanie próbek wykonano zgodnie z zaleceniami producentów. Preparaty biobójcze nanoszono na wszystkie powierzchnie próbek metodą jednorazowego oprysku. Po wyschnięciu próbek, pokrywano je preparatami konsolidującymi lub hydrofobizującymi, trzykrotnie obficie nasączając wszystkie ich powierzchnie za pomocą pędzla. Nasycone próbki pozostawiono na 3 tygodnie w warunkach wilgotności względnej $75 \%$ i temperatury $20^{\circ} \mathrm{C}$. Stworzyło to warunki niezbędne dla poprawnego przebiegu hydrolitycznej polikondensacji roztworu. Po zakończonym sezonowaniu próbki poddano badaniom mikrostrukturalnym w skaningowym mikroskopie elektronowym typu NOVA NANO SEM firmy FEI Company. Na ich podstawie dokonano opisu sposobu wypełnienia przestrzeni porowej oraz wiązania składników mineralnych przez utworzoną substancję wzmacniająca lub hydrofobizująca. Poziom wzmocnienia zwięzłości piaskowców nasyconych preparatami konsolidacyjnymi określono na podstawie zmiany wartości wytrzymałości na ściskanie oznaczonej wg normy PN-EN 1926 w maszynie wytrzymałościowej firmy Proeti o maksymalnym nacisku 5000 kN. Skuteczność hydrofobizacji w próbkach poddanych temu zabiegowi oceniono poprzez obliczenie zmiany wielkości nasiąkliwości wodą zbadanej wg normy PN-EN 13755. Wyniki badań właściwości próbek nasycanych preparatami odniesiono do wartości tych parametrów wykazywanych przez próbki nie poddane impregnacji. 


\section{WYNIKI BADAŃ}

W próbce piaskowca nasyconego preparatem KSE $500 \mathrm{E}$ ziarna mineralne są dokładnie pokryte powłokami żelu krzemionkowego (ryc. 5). Zjawisko to jest także obserwowane w głębszych partiach próbki, do głębokości ok. $10 \mathrm{~mm}$ od powierzchni zewnętrznych. Połączenia pomiędzy ziarnami mineralnymi są silnie rozwinięte, decydując o wyraźnym wzroście zwięzłości piaskowca. Potwierdza to badanie wytrzymałości na ściskanie, która wzrosła w stosunku do stanu przed konsolidacją o $41 \%$ (tab. 1). Również preparat Sarsil OH-500 wyraźnie nasycił pory próbki, wskutek czego żel krzemionkowy obficie wypełnił znaczną część porów. Zadecydowało to o wysokiej skuteczności zabiegu strukturalnego wzmocnienia, co potwierdza wzrost wytrzymałości na ściskanie o 44\% (tab. 1).

Efekt wzmocnienia podobny do opisanego powyżej uzyskano po nasyceniu preparatami KSE 500E i Sarsil OH-500 piaskowców zdezynfekowanych wcześniej preparatem biobójczym Rocima 101. We wnętrzu piaskowca utworzyły się zwarte powłoki żelu (ryc. 6), a jego wytrzymałość na ściskanie wzrosła o 40 i $42 \%$ (tab. 1).

Nasycenie piaskowców preparatami biobójczymi ABM-1, Boramon i IMPULS 70-AN spowodowało, że wykonany później zabieg konsolidacji przy użyciu pre-

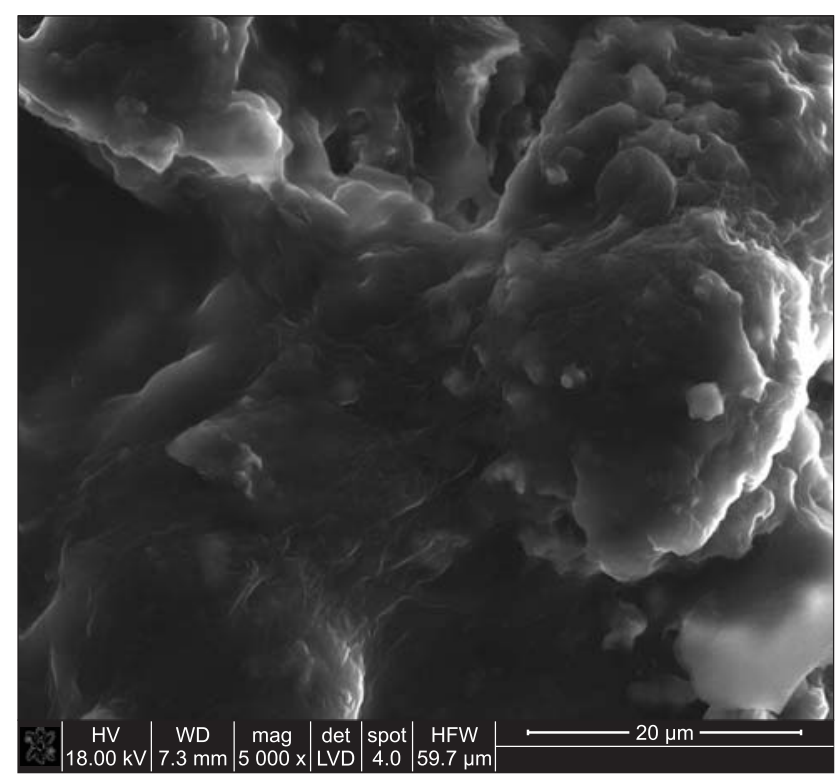

Ryc. 5. Zwarta powłoka żelu krzemionkowego powstałego we wnętrzu piaskowca po zastosowaniu preparatu KSE 500E. Przykład skutecznej konsolidacji. Obraz SEM

Fig. 5. Dense film of the silica gel formed inside the sandstone treated with the KSE 500E consolidating agent. An example of the efficient stone consolidation. SEM image paratów KSE 500E i Sarsil OH-500 okazał się mniej skuteczny. Powstały żel nie utworzył zwartych powłok, ale gruzełkowate skupienia oraz cienkie otoczki na ziarnach mineralnych, które są słabo ze sobą połączone lub nie wykazują takich połączeń w ogóle (ryc. 7). Żelowe połączenia międzyziarnowe stopniowo zanikają w głębszych (powyżej 3-4 mm) częściach próbek. Wytrzymałość na ściskanie piaskowców wzrosła tylko o $31-37 \%$ w stosunku do wytrzymałości próbki porównawczej.

Hydrofobizacja piaskowców preparatami Asolin WS i Funcosil BI doprowadziła do wytworzenia na powierzchni kamienia oraz w jego wnętrzu, cienkich błon dość dobrze oblekających większość cząstek mineralnych (ryc. 8). Wskutek wyraźnego nasycenia dużej części porów piaskowca substancją hydrofobową uzyskano wyraźny, pozytywny efekt impregnacji. Został on potwierdzony obniżeniem nasiąkliwości piaskowców o 49 i 52\% w stosunku do próbek nie poddanych hydrofobizacji (tab. 2).

Zbliżony efekt hydrofobizacji został osiagnięty w próbkach, które nasycono preparatem biobójczym IMPULS 70-AN, a następnie preparatami hydrofobizującymi Asolin WS i Funcosil BI. Powstały żel polisiloksanowy tworzy zwartą powłokę oblekającą ziarna (ryc. 9) sprawiając, że

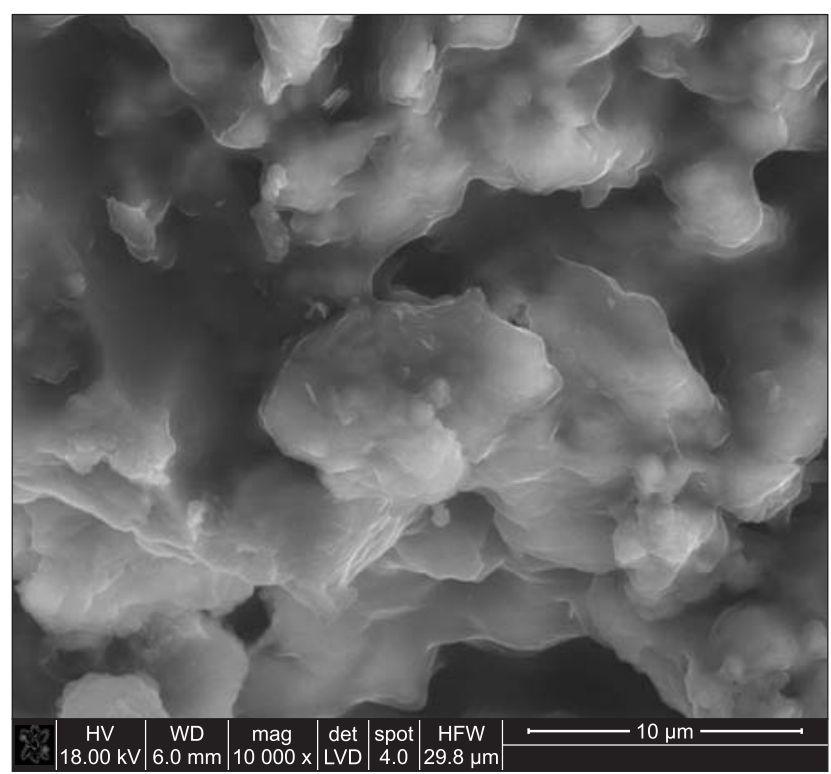

Ryc. 6. Zwięzła powłoka żelu krzemionkowego powstałego po naniesieniu preparatu KSE 500E na powierzchnię piaskowca zdezynfekowanego preparatem biobójczym Rocima 101. Przykład skutecznej konsolidacji. Obraz SEM

Fig. 6. Dense film of the silica gel formed inside the sandstone. The stone was disinfected with the Rocima 101 biocidal, then surface-treated with the KSE 500E consolidating agent. An example of the efficient stone consolidation. SEM image

Tab. 1. Zmiany wytrzymałości na ściskanie piaskowców poddanych działaniu preparatów biobójczych i konsolidacyjnych Table 1. Changes of the compression strength of sandstones treated with biocidal and consolidating chemicals

\begin{tabular}{|c|c|c|c|c|c|}
\hline \multirow{2}{*}{$\begin{array}{l}\text { Wartość parametru } \\
\text { przed nasycaniem [MPa] } \\
\text { Parameter value prior } \\
\text { to saturation [MPa] }\end{array}$} & \multicolumn{5}{|c|}{$\begin{array}{l}\text { Zmiana wartości parametru po nasyceniu [\%] } \\
\text { Change of the parameter value after saturation [\%] }\end{array}$} \\
\hline & KSE $500 \mathrm{E}$ & $\begin{array}{c}\text { Boramon } \\
+ \\
\text { KSE 500E }\end{array}$ & $\begin{array}{c}\text { Impuls } 70-\mathrm{AN} \\
+ \\
\text { KSE 500E }\end{array}$ & $\begin{array}{c}\text { Rocima } 101 \\
+ \\
\text { KSE 500E }\end{array}$ & $\begin{array}{c}\text { ABM-1 } \\
+ \\
\text { KSE 500E }\end{array}$ \\
\hline \multirow{3}{*}{38,8} & +41 & +32 & +37 & +40 & +35 \\
\hline & $\begin{array}{c}\text { Sarsil } \\
\mathrm{OH}-500\end{array}$ & $\begin{array}{c}\text { Boramon } \\
\stackrel{+}{+} \\
\text { Sarsil } \stackrel{\mathrm{OH}}{-} 500\end{array}$ & $\begin{array}{c}\text { Impuls } 70-\mathrm{AN} \\
+ \\
\text { Sarsil } \\
\mathrm{OH}-500\end{array}$ & $\begin{array}{c}\text { Rocima } 101 \\
+ \\
\text { Sarsil } \\
\text { OH-500 }\end{array}$ & $\begin{array}{c}\text { ABM-1 } \\
\stackrel{+}{\text { Sh-500 }} \\
\text { Sarsil }\end{array}$ \\
\hline & +44 & +31 & +35 & +42 & +37 \\
\hline
\end{tabular}


nasiąkliwość kamienia jest niższa w stosunku do próbek nieimpregnowanych o 46 i $51 \%$ (tab. 2).
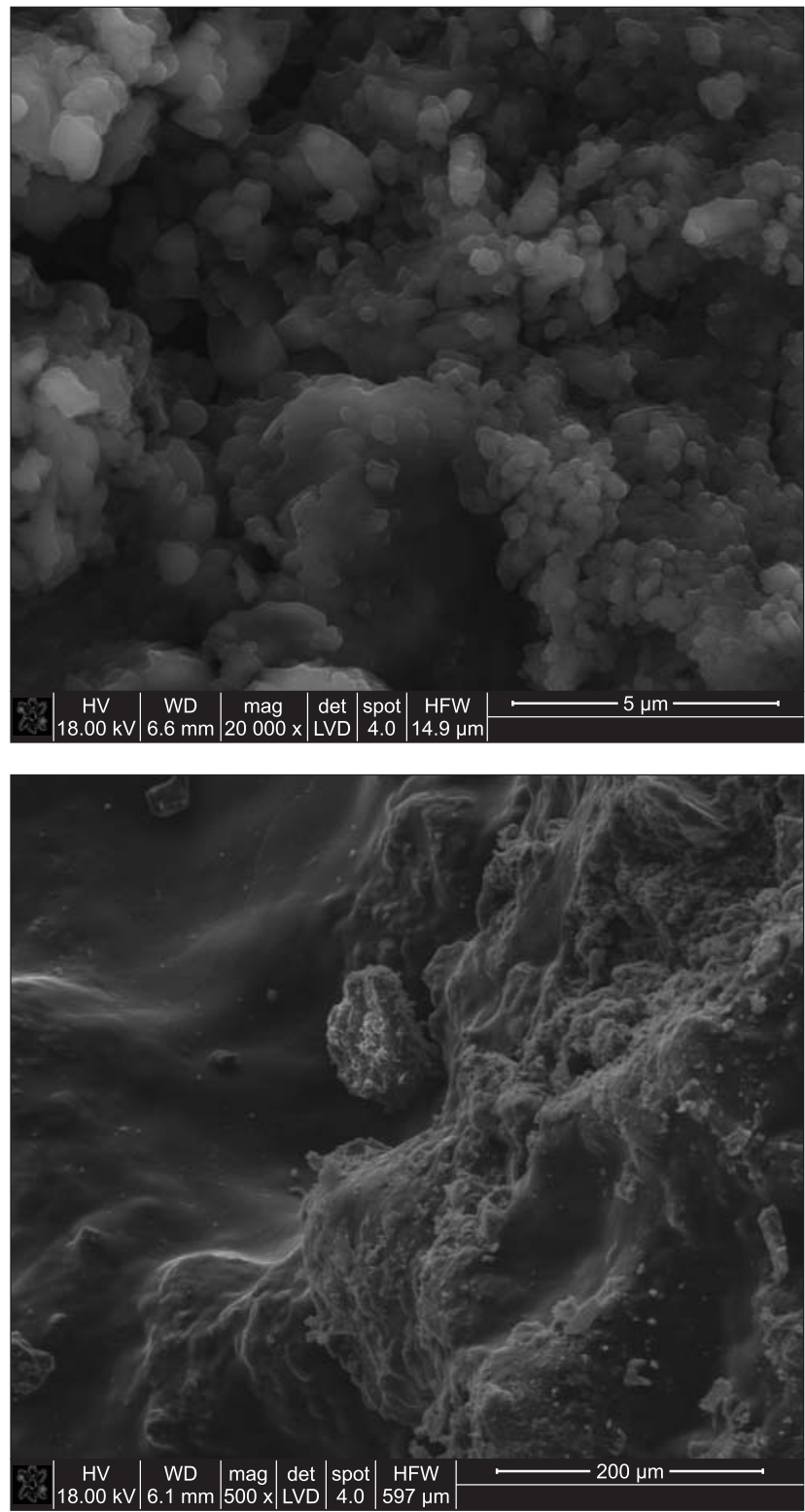

Ryc. 8. Zwięzła i szczelna powłoka żelu polisiloksanowego powstałego we wnętrzu piaskowca po zastosowaniu preparatu Funcosil BI. Przykład skutecznej hydrofobizacji. Obraz SEM Fig. 8. Dense and tight film of the polysiloxane gel formed inside the sandstone. The stone was treated with the Funcosil BI hydrophobic agent. An example of the efficient stone hydrophobization. SEM image
Negatywny wpływ na skuteczność hydrofobizacji wykonanej preparatami Asolin WS i Funcosil BI miało wcześniejsze zastosowanie preparatów Rocima 101 i ABM-1. Na powierzchni kamienia powstały cienkie, spękane powłoki (ryc. 10), a w strefie do głębokości 1,6-3,8 mm jedynie drobne, wzajemnie izolowane cząstki żelu. W stosunku do próbki porównawczej wartość nasiąkliwości uległa obniżeniu o $35-44 \%$ (tab. 2).

$\leftarrow$

Ryc. 7. Cząstki żelu krzemionkowego nie tworzące zwartej powłoki, powstałe po zastosowaniu preparatu KSE 500E na powierzchnię zdezynfekowana preparatem IMPULS 70-AN. Przykład nieskutecznej konsolidacji piaskowca. Obraz SEM

Fig. 7. Particles of the silica gel do not form a dense film inside the sandstone. The stone was disinfected with the IMPULS 70-AN biocidal, then surface-treated with the KSE 500E consolidating agent. An example of the inefficient stone consolidation. SEM image

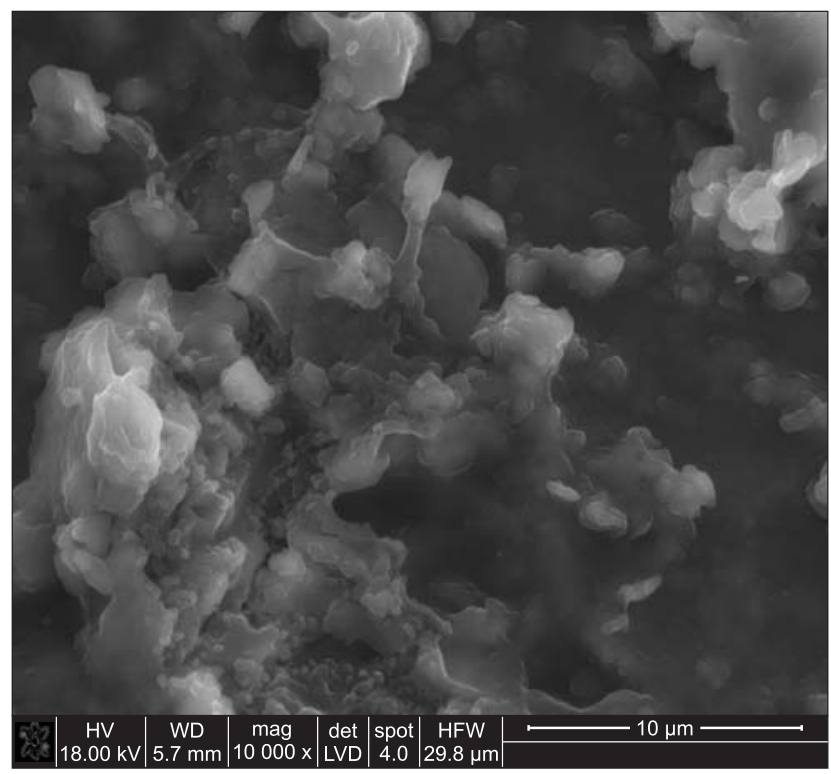

Ryc. 9. Szczelna powłoka żelu polisiloksanowego powstałego po naniesieniu preparatu Funcosil BI na powierzchnię piaskowca zdezynfekowaną preparatem IMPULS 70-AN. Przykład skutecznej hydrofobizacji. Obraz SEM

Fig. 9. Tight cover of the polysiloxane gel formed inside the sandstone. The stone was disinfected with the IMPULS 70-AN biocidal, then surface-treated with the Funcosil BI hydrophobic agent. An example of the efficient stone hydrophobization. SEM image

Tab. 2. Zmiany nasiąkliwości piaskowców poddanych działaniu preparatów biobójczych i hydrofobizujących Table 2. Changes of the water absorbability of sandstones treated with biocidal and consolidating chemicals

\begin{tabular}{|c|c|c|c|c|c|}
\hline \multirow{2}{*}{$\begin{array}{l}\text { Wartość parametru } \\
\text { przed nasycaniem } \\
\text { [\% wag.] } \\
\text { Parameter value prior } \\
\text { to saturation } \\
\text { [wt. \%] }\end{array}$} & \multicolumn{5}{|c|}{$\begin{array}{l}\text { Zmiana wartości parametru po nasyceniu [\%] } \\
\text { Change of the parameter value after saturation [\%] }\end{array}$} \\
\hline & Asolin WS & $\begin{array}{c}\text { Boramon } \\
+ \\
\text { Asolin WS }\end{array}$ & $\begin{array}{c}\text { Impuls } 70-\mathrm{AN} \\
+ \\
\text { Asolin WS }\end{array}$ & $\begin{array}{c}\text { Rocima } 101 \\
+ \\
\text { Asolin WS }\end{array}$ & $\begin{array}{c}\text { ABM-1 } \\
+ \\
\text { Asolin WS }\end{array}$ \\
\hline \multirow{3}{*}{8,11} & -52 & -42 & -51 & -43 & -44 \\
\hline & Funcosil BI & $\begin{array}{c}\text { Boramon } \\
+ \\
\text { Funcosil BI }\end{array}$ & $\begin{array}{c}\text { Impuls 70-AN } \\
+ \\
\text { Funcosil BI }\end{array}$ & $\begin{array}{c}\text { Rocima } 101 \\
+ \\
\text { Funcosil BI }\end{array}$ & $\begin{array}{c}\text { ABM-1 } \\
+ \\
\text { Funcosil BI }\end{array}$ \\
\hline & -49 & -48 & -46 & -35 & -39 \\
\hline
\end{tabular}




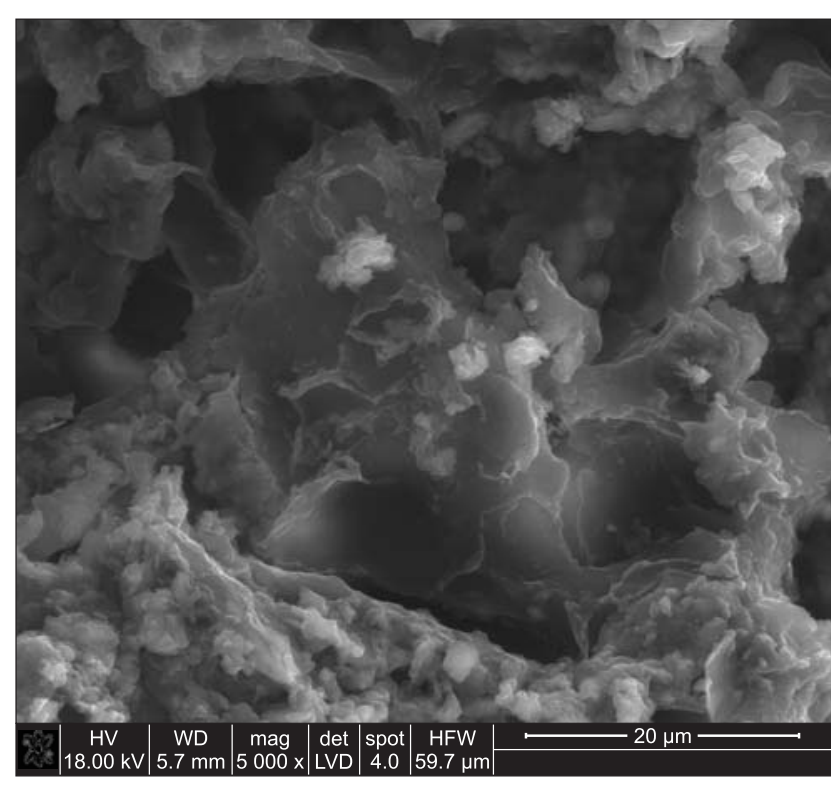

Ryc. 10. Cienka, spękana powłoka żelu polisiloksanowego powstałego po naniesieniu preparatu Funcosil BI na powierzchnię piaskowca zdezynfekowaną preparatem Rocima 101. Przykład nieskutecznej hydrofobizacji. Obraz SEM

Fig. 10. Thin and fractured film of the polysiloxane gel formed inside the sandstone. The stone was disinfected with the Rocima 101 biocidal, then surface-treated with the Funcosil BI hydrophobic agent. An example of the inefficient stone hydrophobization. SEM image

Preparat biobójczy Boramon wykazał zróżnicowany wpływ na efektywność zabiegu hydrofobizacji. W przypadku zastosowania preparatu Funcosil BI powstały ciągłe jednorodne powłoki, a nasiąkliwość uległa obniżeniu aż o $48 \%$. Natomiast żel powstały z preparatu Asolin WS utworzył się jedynie na powierzchni kamienia. Powstałe powłoki są spękane i pokryte pęcherzami. Nasiąkliwość kamienia uległa zmniejszeniu tylko o $42 \%$.

\section{WNIOSKI}

Badania wykazały, że o skuteczności zabiegu konsolidacji i hydrofobizacji decyduje mikrostruktura żelu polisiloksanowego, który powstaje z kondensacji preparatów wprowadzonych do wnętrza kamienia. Niektóre preparaty biobójcze, pomimo deklarowanej przez producentów niskiej reaktywności chemicznej, wpływają na zmianę fizycznych lub chemicznych właściwości podłoża. Powoduje to zaburzenia w rozwoju powłok żelowych w kamieniu, co przekłada się na mniejszą skuteczność zabiegu hydrofobizacji i konsolidacji. Z tego względu konieczne jest ograniczanie do minimum ilości preparatu biobójczego wprowadzanego do wnętrza kamienia, najlepiej poprzez dostosowywanie jego rodzaju do typu i ilości mikroorganizmów zasiedlających kamień. Niezbędny jest także odpowiedni dobór preparatów wprowadzanych równocześnie do kamienia, pod względem ich składu chemicznego, co pozwoli na ograniczenie możliwości niepożądanych interakcji między nimi.

Autor składa podziękowanie Recenzentom oraz Redakcji Przeglądu Geologicznego za poświęcony czas oraz cenne uwagi dotyczące treści artykułu i jego formy.
Praca została zrealizowana na Wydziale Geologii, Geofizyki i Ochrony Środowiska Akademii Górniczo-Hutniczej w Krakowie, finansowana przez Ministerstwo Nauki i Szkolnictwa Wyższego ze środków przeznaczonych na naukę.

\section{LITERATURA}

ABE Y., GUNJI T. 2004 - Oligo- and polysiloxanes. Prog. Polym. Sci., 29: $149-182$.

ALLSOPP D., SEAL K., GAYLARDE C. 2004 - Introduction to Biodeterioration. Cambridge University Press, $1-237$.

AMOROSO G.G., FASSINA V. 1983 - Stone decay and conservation: atmospheric pollution, cleaning, consolidation and protection. Elsev. Sci. Publishers, $1-453$

ARNOLD L. 1978 - The preservation of stone by impregnation with silanes. Newsletter of the Council for Places of Worship, 24: 4-6.

DADLEZ R., FELDMAN-OLSZEWSKA A., KOPIK J., MATYJA B.A., PIEŃKOWSKI G. 2008 - Tabela stratygraficzna Polski. Polska pozakarpacka. Jura. Państw. Inst. Geol. Wyd. Ministerstwa Środowiska, Warszawa. DECZKOWSKI Z., FRANCZYK M. 1988 - Paleomiążzzość, litofacje i paleotektonika epikontynentalnej jury dolnej w Polsce. Kwart. Geol., 32 (1): 105-116.

FAVARO M., MENDICHI R., OSSOLA F., RUSSO U., SIMON S., TOMASIN P., VIGATO P.A. 2006 - Evaluation of polymers for conservation treatments of outdoor exposed stone monuments, Part I: Photo-oxidative weathering. Polym. Degrad. Stab., 91 (12): 3083-3096.

FERNANDES P. 2006 - Applied microbiology and biotechnology in the conservation of stone cultural heritage materials. App. Microbiol. Biotechnol., 73: 291-296.

FERREIRA PINTO A.P., DELGADO RODRIGUES J. 2008 - Stone consolidation: The role of treatment procedures. J. Cult. Herit., 9: 38-53. FLORES M., LORENZO J., GÓMEZ-ALARCÓN G. 1997 - Algae and bacteria on historic monuments at Alcala de Henares, Spain. Int. Biodeterior. Biodegrad., 40 (2-4): 241-246.

GARG K.L., DHAWAN S., AGRAWAL O.P. 1988 - Deterioration of stone and building materials by algae and lichens: a review. Government of India, Department of Culture, National Research Laboratory for Conservation of Cultural Property, 1-43.

GRISSOM C.A., WEISS N.R. 1981 - Alkoxysilanes in the conservation of art and architecture: 1861-1981. Art. Archaeol. Techn. Abstr., 18 (1): $150-202$.

ORTEGA-CALVOA J.J., HERNANDEZ-MARINE M., SAIZ-JIMENEZ C. 1991 - Biodeterioration of building materials by cyanobacteria and algae. Int. Biodeterior., 28 (1-4): 165-185.

MAREK S., PAJCHLOWA M. (red.) 1997 - Epikontynentalny perm i mezozoik w Polsce. Pr. Państw. Inst. Geol., 153: 452

PINNA D., SALVADORIA B., GALEOTTI M. 2012 - Monitoring the performance of innovative and traditional biocides mixed withconsolidants and water-repellents for the prevention of biological growth on stone. Sci. Total Environ., 423: 132-141.

PN-EN 1926 - Metody badań kamienia naturalnego. Oznaczanie wytrzymałości na ściskanie. PKN, Warszawa.

PN-EN 13755 - Metody badań kamienia naturalnego. Oznaczanie nasiąkliwości przy ciśnieniu atmosferycznym. PKN, Warszawa.

PRIKRYL R., SMITH B.J. 2007 - Building Stone Decay: From Diagnosis to Conservation. Geol. Soc., London, Spec. Publ., 271: 1-323.

REMBIŚ M. 2013 - Modyfikacja fizyczno-mechanicznych właściwości piaskowców metodą strukturalnego wzmacniania skał preparatami zawierającymi tetraetoksysilan. Wyd. AGH, seria: Rozprawy, Monografie, 270: $1-182$

SCHNABEL L. 1991 - The treatment of biological growths on stone: a conservator's viewpoint. Int. Biodeterior., 28 (1-4): 125-131.

SIEGESMUND S., SNETHLAGE R. 2011 - Stone in Architecture. Properties, Durability. Springer Heidelberg, Dordrecht, London, New York, $1-552$.

WARSCHEID T.H., BRAAMS J. 2000 - Biodeterioration of stone: a review. Int. Biodeter. Biodegrad., 46 (4): 343-368.

WEBER H. 1975 - Stone Renovation and Consolidation Using Silicones and Silicic Esters. [W:] Rossi-Manaresi R. (red.), The Conservation of Stone I. Proceed. of the Int. Symp., Bologna, June 19-21 1975, 375-385. WHEELER G. 2005 - Alkoxysilanes and the consolidation of stone, The Getty Conservation Institute, Research in Conservation, Los Angeles: $1-196$. 